\title{
External and Domestic Drivers of Inflation: The Case Study of Hungary ${ }^{1}$
}

\author{
Erzsébet Éva Nagy, Central Bank of Hungary \\ nagyer@mnb.hu \\ Veronika Tengely, Central Bank of Hungary \\ tengelyv@mnb.hu
}

\begin{abstract}
Subdued global economic activity, declining energy and commodity prices, the appearance of new technological innovations and inflation expectations anchored at historically low levels around the world were all factors that have tended to result in declining inflation rates at the global level since 2013. The relationship between globalization and inflation is a popular research topic among economists. According to the majority of the body of literature, globalization's and external factors' influence on national inflation rates increased in recent years. In this paper we investigate, how external and domestic drivers affect the Hungarian inflation. Hungary is an interesting case study, since openness of the country grew significantly, thus Hungary became one of the most open economy in the EU. The Hungarian experience can thus be interesting for countries with an increasing trend of openness. Using several statistical methods, we examined and analyzed the impact of external and domestic drivers of the Hungarian inflation, and how these external factors varied in time and how their effect on the domestic inflation has changed. Our results show, that the role of external factors in domestic inflation developments strengthened in the past period, and especially after 2012, the changes in inflation in Hungary were mainly influenced by external effects.
\end{abstract}

Keywords: external factors, globalization, inflation, Phillips curve, principal components, SVAR models

JEL Codes: C53, E31, E37, F02, F41, F62
Citation: Nagy, E.E. and Tengely, V. (2018). External and Domestic Drivers of Inflation: The Case Study of Hungary. Russian Journal of Money and Finance, 77(3), pp. 49-64.

doi: $10.31477 /$ rjmf.201803.49

\section{Introduction}

Subdued global economic activity, declining energy and commodity prices, the appearance of new technological innovations and inflation expectations anchored at historically low levels around the world were all factors that have

\footnotetext{
${ }^{1}$ The views expressed are those of the authors and do not necessarily reflect the official view of the Central Bank of Hungary (Magyar Nemzeti Bank, MNB).
} 
tended to result in declining inflation rates at global level since 2013. As a result of the rising commodity prices at the end of 2016 and in early 2017, inflation rates moved away from close-to-zero levels, but still tended to fall short of central bank targets.

In contrast to global inflation rates, economic performance has varied from region to region after the crisis, which is also corroborated by the significantly different levels of unemployment in the European Union (Figure 1, left panel). We have split the sample in 2012. The reason behind this, on the one hand, is that after the global financial crisis in 2008, the euro area faced its sovereign debt crisis with the deepest recession in 2012. With the help of the ECB programmes and the measures taken by EU policy leaders, financial stability improved significantly, and economic growth also showed a turning point. On the other hand, this turning point can also be observed on the case of the EU unemployment rate, which started to gradually decrease from the second half of 2012. Taking inflation rates into account, the inflation range of all EU countries became significantly narrower after 2012 and this has remained so since then. After 2012 the standard deviation of unemployment rates in the EU countries increased remarkably. Despite the different phase of the labour market cycle, no divergence could be detected in inflation dynamics, indeed, inflation rates tended to remain at generally low levels in recent years (Figure 1, right panel). Regarding that, the question arises: what role might global, common factors play in these developments?

Figure 1. Standard deviations of unemployment rates and inflation rates in the EU

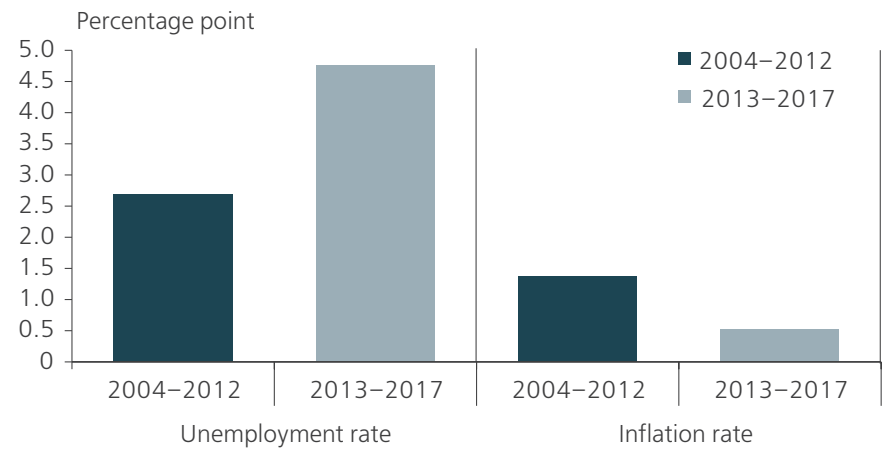

Source: Eurostat, $M N B$

The most common reasons behind the strengthening correlation between inflation rates are globalization and - together with that factor - integration into global production processes (the role of global value chains), which may have amplified the impact of international business cycles on inflation. The effect of globalization is perceived through various channels. Increased trade openness, higher competition as a result of economic integration, the global division of 
labour and the appearance of new low-cost labour in the production chains all result in more restrained price dynamics and increased co-movement of national inflation rates. As a stylised fact, we can mention the increasing share of industrial workers in developing countries, which lowers global inflation (Figure 2). The process was remarkable mainly in the pre-crisis period, when the developing countries became even more involved into the international trade, and as a result of this, the amount of available low-cost labour rose dynamically.

Figure 2. Global inflation and the share of industrial workers in developing countries

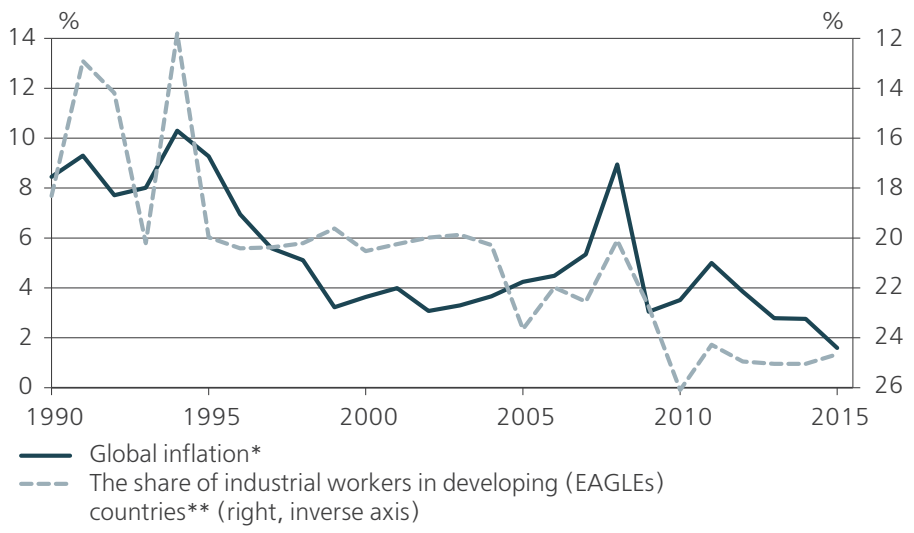

Note: ${ }^{*}$ Annual change. ${ }^{* *}$ EAGLEs stand for Emerging and growth-leading economies and includes those countries, whose contribution to the world economic growth will exceed the average of the G7 economies excluding the USA. The EAGLE economies are Brazil, India, Indonesia, China, Mexico, Russia and Turkey.

Source: World Bank

This paper is a case study of Hungary, a small open economy. Since Hungary became extremely open in the last two decades, it is an important role of model how trade openness alters the inflation dynamics. Nowadays the export-to-GDP ratio is above $90 \%$, which is well above the average of the European Union and the average of the Visegrad countries as well (Figure 3). ${ }^{2}$ As Hungary became more and more open, according to our hypothesis the role of the external factors driving the Hungarian economy increased. In this paper, we investigate the effects of these external factors on one of the most important economic indicators, the inflation rate.

\footnotetext{
2 The Visegrad countries include the Czech Republic, Poland, Slovakia, and Hungary. In our estimations and analysis we eliminate Hungary because it would distort the results. We have chosen the export-to-GDP ratio as a trade openness indicator. In the case of Hungary and the Visegrad countries except Slovakia it is the most appropriate indicator of trade openness, because the import content of the export is relatively high in these countries, around $50-60 \%$.
} 
Figure 3. Trade openness in Hungary, in the region and in the European Union

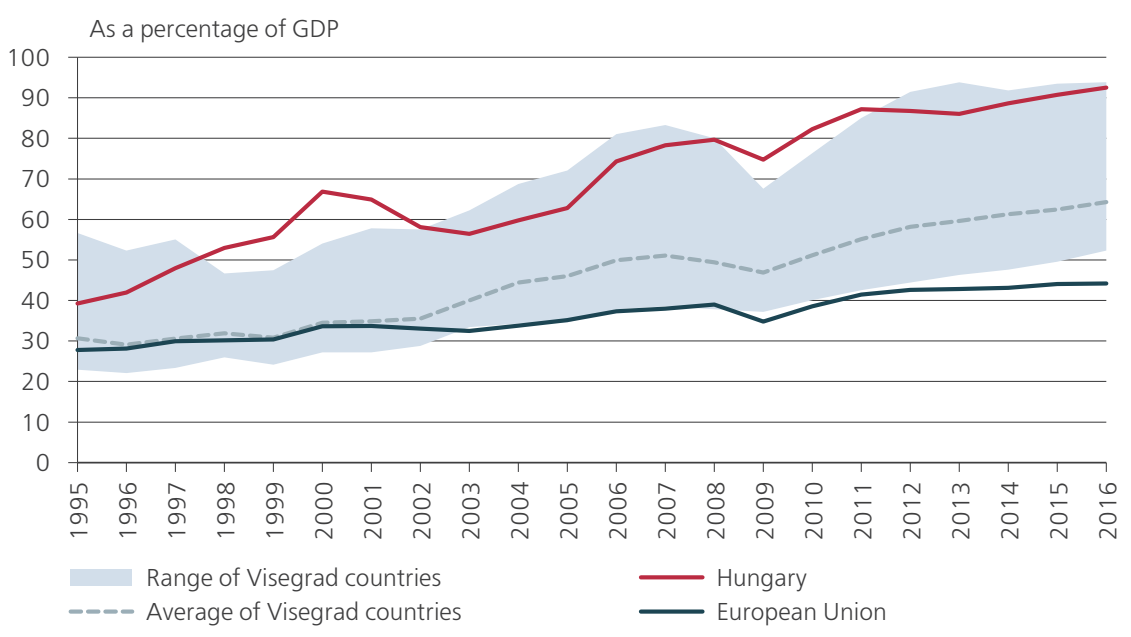

Note: The band indicates the range of export-to-GDP ratio of the Visegrad countries (Hungary excluded): the Czech Republic, Poland and Slovakia.

Source: Eurostat

Figure 4. Distribution of correlations by pair between the inflation rates of the countries of the European Union

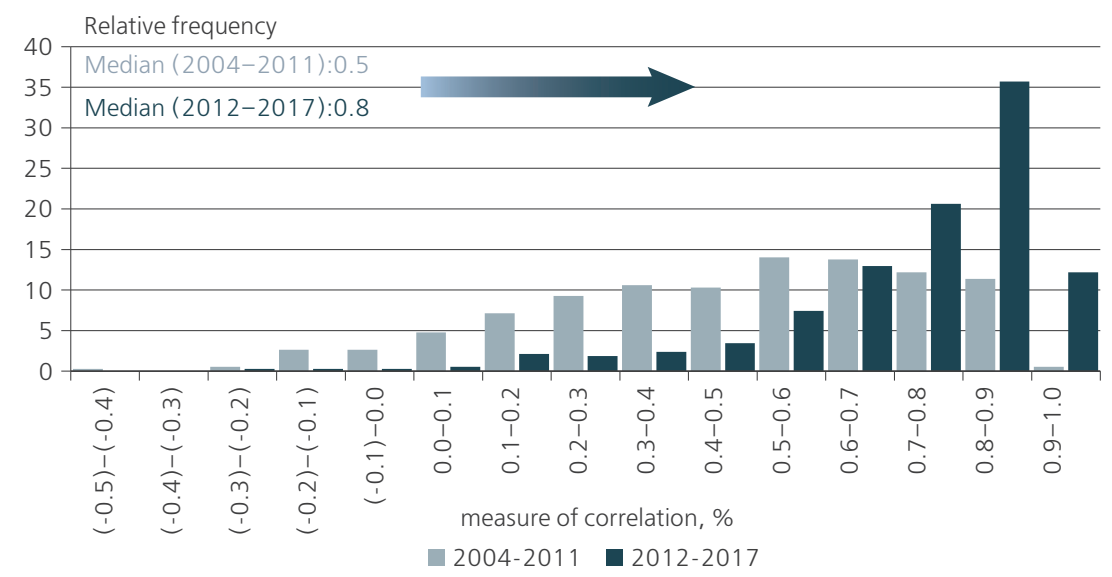

Note: Relative frequency. The figure shows the distribution of pairwise correlations between the EU countries. For example the $0.8-0.9$ correlation has to be interpreted in a way that while between 2004201111.4 percent of the pairings were characterised by a correlation between 0.8 and 0.9 , this ratio rose to 35.7 percent after 2012 .

Source: Eurostat, MNB 
In case of Hungary, the European Union represents the narrower global environment, as approximately $80 \%$ of Hungary's foreign trade is with the EU. Therefore, it is worth examining historical developments in EU inflation rates. We can conclude that the Hungarian example is not unique. Correlation among the price indices of the EU countries has increased considerably in the past years (Figure 4). While the median of the distribution of partial correlations has been moderate before 2012, the correlation coefficient rose to above 0.8 after 2012 .

The remaining structure of the paper is as follows. Section 2 reviews the relevant literature. In Section 3 we describe the methodology and present the estimation results. Section 4 concludes.

\section{Literature review}

The impact of common - or global - factors on the national inflation rates gained growing attention in recent years. According to Guerrieri et al. (2010), globalization and economic integration affect inflation processes through various channels. On the one hand, because of globalization, inflation is less sensitive to the internal capacity constraints: this means, that a sudden demand growth can increase import without raising prices. On the other hand, economic integration enhances global competition, which can hold back price dynamics. These statements are in line with the results supporting the flattening of the Phillips curve after the financial crisis. Taking the wage Phillips curves into account, international results vary significantly (Bulligan and Viviano, 2016; Muto and Shintani, 2014). According to them, in Germany the connection between wage inflation and unemployment weakened, while in France, Italy and Spain strengthened. In Hungary, the slope of the wage Phillips curve is relatively stable in time: after the crisis it increased slightly, but since 2014 it has become weaker.

The traditional Phillips curve represents the connection between inflation and domestic economic slack. It does not contain global factors, so the inflationary effect of the external economic environment appears only indirectly. This makes such a model too country-specific. Due to the enhanced effect of globalization, common factors should be taken into consideration directly. The new fashion Phillips curves are external-factors-augmented Phillips curves to measure the effects of global economic slack.

The above mentioned, new Phillips curve estimations proved, that common factors not only have greater inflationary effects, but they reduce national inflation rates while increasing the correlation between them. The evolution of commodity prices - especially crude oil prices - probably contributes to the latter, but this distorting effect can be easily removed with the use of the core inflation rate (or such an inflation rate, which excludes at least fuel prices).

The role of global factors in inflation developments increased mainly after the financial crisis, but there are pre-crisis estimates (see Morimoto et al., 2003; 
Ciccarelli and Mojon, 2005; Bean, 2006; Fisher, 2006; Mumtaz and Surico, 2008; Yellen, 2006; Bernanke, 2007), which could measure and prove the importance of common factors before the crisis especially in the case of developed countries. Borio and Filardo (2007) estimated a Phillips curve for 16 developed countries, which contained besides the domestic output gap the so called global output gap, the oil prices and the import prices to measure the change in the inflation processes.

In the post-crisis period, the literature emphasizing the role of global factors increased further (see Ciccarelli and Mojon, 2010; Caruana, 2012; Carney, 2015; Fischer, 2015; Jordan, 2015; Draghi, 2016; Poloz, 2016). Those, who support the theory of the globalization of inflation point at the role of the global value chains (see Auer et al., 2017; Borio et al., 2017; Nickel, 2017). Global value chains contribute to the strengthening of the co-movement of inflation rates, because the international input-output linkages synchronise not only the national inflation rates with each other, but with the global processes as well. According to the globalization of inflation hypothesis, the geographically more fragmented global production processes made the spread of new technologies possible and reduced or abolished trade barriers. In those economies, whose trade openness is greater, wage and price dynamics are more sensitive to the external effects, which blows up the role of common factors. In parallel with the gaining momentum of the global value chains, the domestic factors have only limited effect on inflation.

Besides the role of global value chains, Borio (2017) emphasizes that one may underestimate globalization's influence on inflation. According to him, because of the well-anchored inflation expectations and because of the greater contestability from more integrated product, labour and capital markets, the link between domestic slack and inflation has become weak and elusive. This indicates, that globalization has two types of effects on inflation: the symmetrical effect is, that inflation is more sensitive to global slack, and the asymmetrical effect is the secular downward pressure on inflation stemming from the lower-cost producers and the more and cheaper labour.

According to the ECB (ECB Economic Bulletin, 2017), the role of global factors depends heavily on the estimation sample and on the measurement of the output gap, so it is not surprising, that the literature provides contradictory results as well. For example, while in the case of developed countries, Borio and Filardo (2007) and, in the case of the USA, Milani (2009) proved the increasing role of global factors, Calza (2008), Gerlach et al. (2009), Ihrig et al. (2010), MartínezGarcía and Wynne (2010), as well as Eickmeier and Pijnenburg (2013) could not find any significant explanatory power of those factors. The ECB (2017) study applies a Phillips curve, which implies the inflation expectations as a forwardlooking part. They found, that the global factors drive the euro area inflation only between 2008-2009, but between 2012-2015 domestic factors are dominating. 


\section{Methotodology and estimation results}

According to the literature, the role of global - or common - factors may have become increasingly important in domestic inflation developments as well. In order to find out, whether this is also true in the case of Hungary, we made estimates with the help of several methods. ${ }^{3}$

\subsection{Determining the drivers of the Hungarian inflation using principal component analysis}

The Principal Component Analysis (PCA) is a useful statistical technique to investigate the effect of a phenomenon or a variable, which is hardly or not observable. In the case of Hungary, we are not able to measure the common as well as the regional factors, so we generated these latent variables with the help of the inflation time series of the EU member states. With the help of the PCA, we were able to decompose the variance of the Hungarian inflation into global, regional and country-specific effects. Global factors capture the impact of EU member countries' inflation rates on the domestic price index and comprise the effect of the changes in oil prices as well. Regional factors capture the inflationary effects stemming from the Visegrad countries except Hungary (the Czech Republic, Poland, Slovakia). All other effects unexplained by the global and regional factors, are the idiosyncratic or country-specific components.

For the decomposition, we used the methodology developed by Krusper (2012) based on Stock-Watson (2002). The external and country-specific factors are constructed consistently with a two-step procedure. First, all inflation time series of the EU countries - are used to estimate the common factor. This factor captures all of the effects, which influence the inflation time series of the EU countries. Then we subtract the global component by regressing this common factor on inflation, and take the residuals, which are now independent from global (or common) effects. Second, we calculate the regional factor in the same way with another PCA using the residual time series only. After that, to compute the idiosyncratic component for Hungary and the Visegrad countries, we simply regress the common and regional factors on the individual inflation time series of each analyzed country. The equation stated with estimated common and regional factors for domestic inflation:

$$
\pi_{i t}=\beta_{i 1} g_{t}+\beta_{i 2} r_{t}+\varepsilon_{i t},
$$

where $\pi_{i t}$ is the actual, standardised domestic inflation (HICP), ${ }^{4} g_{i t}$ indicates the common factor, $r_{i t}$ the regional factor and $\varepsilon_{i t}$ the country-specific factor. In

\footnotetext{
${ }^{3}$ An extract of these estimates was published in the September 2017 Inflation Report of the MNB (MNB, 2017).

${ }^{4}$ HICP: Harmonised Index of Consumer Prices. For summary statistics of the data used for the PCA analysis see Appendix Table 2.
} 
the subscript, $i$ refers to the country. This methodology is a useful tool to separate the contributions of individual factors to inflation. At the same time, it does not provide a structural explanation for developments in inflation, as it analyses the correlation between various inflation time series.

Figure 5. Decomposition of inflation according to global, regional and idiosyncratic factors

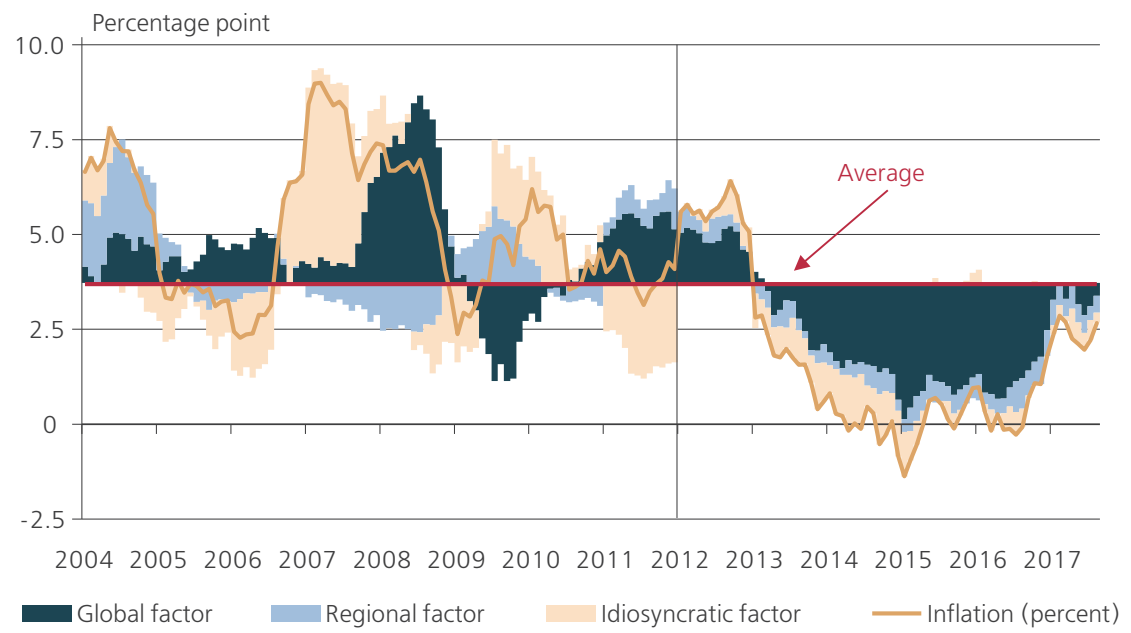

Note: Annual change. The factors explain the deviation of actual inflation (HICP) from its average between 2004-2017.

Source: Eurostat, $M N B$

The deviation of inflation from its long-term average was primarily explained by global factors in the past years; the significance of country-specific and regional effects is much lower. The impact of regional factors was perceived to a greater extent in the period of joining the EU. The contribution of country-specific factors is mainly explained by the changes in taxes and regulated prices, ${ }^{5}$ although their effect declined significantly in the past years. Since 2012, domestic inflation developments have mainly (up to 70-80\%) been determined by the global factor, in line with the stronger co-movement of international inflation rates (Figure 5). We estimated this model using the time series of the Czech Republic, Poland and Slovakia. In the case of these three Visegrad countries we experienced the dominance of the global factors after 2012 (see Figure 8, Figure 9 and Figure 10 in the Appendix). For the variance decomposition in the estimation period (20042017) see Table 3 in the Appendix.

\footnotetext{
${ }^{5}$ General VAT increased in January 2004, September 2006 and July 2009. In September 2006 there was also an increase in overhead expenses. Hungary experienced a general VAT cut only once, in January 2006.
} 


\subsection{Identifying the external drivers of the domestic inflation using SVAR approach}

To identify the external drivers of the Hungarian inflation, we applied a twostep estimation method on disaggregated inflation data. ${ }^{6}$ First, we estimated a SVAR model to get the time series of the selected external shocks. Second, we regressed the disaggregated price indices of the main inflation groups on the identified global shocks and on some domestic variables controlling for the prevailing inflation target of the MNB. Finally, we constructed the overall external and internal - or domestic - effects on the Hungarian inflation excluding regulated prices and the effect of indirect taxes. ${ }^{7}$

We have done the estimation using quarterly frequency data - both levels ${ }^{8}$ and quarterly changes - between 2003Q1 and 2017Q2 (Appendix, Table 4). As we mentioned in Section 1, because of economic reasons, the external environment in the case of Hungary is the European Union, or rather the euro area. In order to estimate the impact of the external shocks, we formed a model with the variables reflecting the euro area cyclical position (as a demand shock), the global commodity prices (as a commodity-specific shock), the euro area inflation (as a supply shock) and the interest rates in the euro area (as a monetary policy or interest rate shock). The variable used to capture the external demand shock was the output gap of the euro area based on the estimation of the European Commission.

The four-dimensional Bayesian SVAR model with one period lag was estimated using sign restrictions (Appendix, Table 5) according to the statistical method developed by Dieppe et al. (2016). These sign restrictions were needed not to hurt the classical economic relationships between the demand and supply changes, or between the inflation and interest rates. The results of the estimation the time series of the external shocks and the impulse responses - can be seen in the Appendix (Figure 11, Figure 12).

After we got the time series of the external shock variables we formed different OLS-regression models in the case of the main inflation groups: food, industrial goods, services and fuel. These groups together form the Hungarian inflation excluding regulated prices, which we would like to construct and analyze later from the results of the disaggregated estimations. The equation stated with estimated external shocks for domestic inflation of the selected groups:

$$
\begin{aligned}
& \pi_{i, t}=c+\beta_{1} \pi_{i, t-1}+\beta_{2} e^{D}+\beta_{3} e^{C}+\beta_{4} e^{S}+ \\
& +\beta_{5} e^{R}+\beta_{6} \gamma_{t-h}+\beta_{7} \pi_{t}^{e}+\varepsilon_{t}
\end{aligned}
$$

\footnotetext{
${ }^{6}$ A similar estimation method was used by Hałka and Kotłowski (2016) on Czech, Polish and Swedish inflation data.

${ }^{7}$ We have chosen this inflation indicator to analyze because indirect taxes and regulated prices depend on government decisions, which we cannot explain either by external but or internal variables.

${ }^{8}$ In the case of the output gap and the services sector's expectations.
} 
where $\pi_{i, t}$ is the quarterly inflation in the $i$-th group, $c$ is the constant in the case of food, industrial goods and fuel, and the prevailing inflation target of the central bank (Appendix, Table 7) in the case of services. The external demand, commodity-specific, supply and interest rate shocks are indicated by $e^{D}, e^{C}, e^{S}$ and $e^{R}$. The variable $\gamma_{t-h}$ indicates the cyclical position of Hungary. This is the output gap for the industrial goods, and the consumption gap in the case of food and services. The lag of the gap variable $(h)$ was chosen to maximize the average adjusted $\mathrm{R}^{2}$ across the regressions. According to the estimations $h=3$ was the best choice. In the equation $\pi_{t}^{e}$ represents the Hungarian domestic inflation expectations, in the case of services the services sector's expectations. ${ }^{9}$

Figure 6. The decomposition of inflation drivers

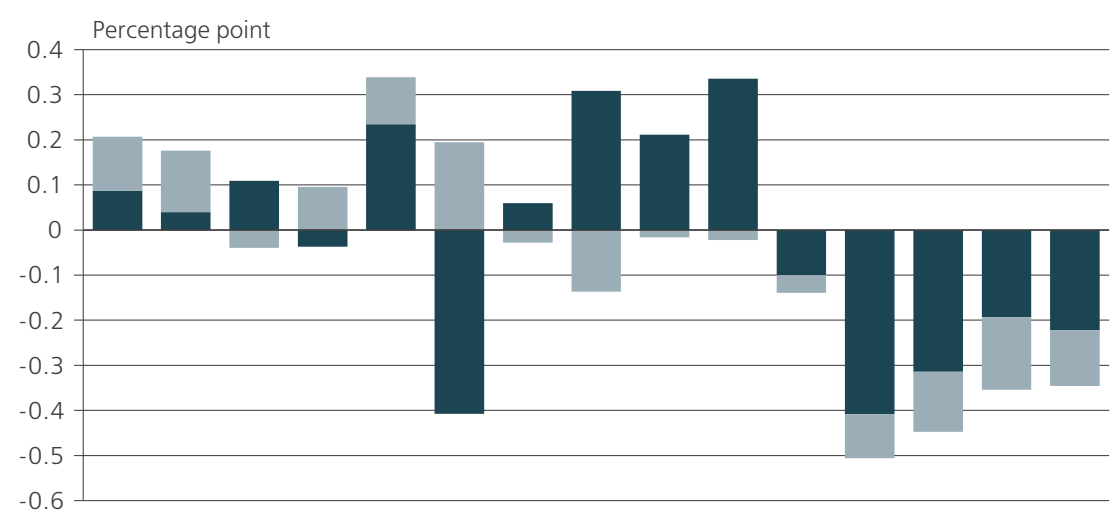

200320042005200620072008200920102011201220132014201520162017

- External drivers of inflation

Internal drivers of inflation

Note: The inflation indicator is the quarterly change in inflation excluding regulated prices and the effect of indirect taxes. External drivers are the effects of the external demand, commodity-specific, supply and interest rate shocks. Internal drivers include the effects of the domestic slack and the domestic inflation expectations.

Source: $M N B$

In all of the regressions we used only the significant explanatory variables at $15 \%$ significance level similarly to the consensus of the literature and researches like Hałka and Kotłowski (2016). ${ }^{10}$ If we look at Table 6 in the Appendix where we summarise the estimation results - we can see, that in the case of industrial goods, services and fuel, the parameters are significant at 5\% level. This indicates, that these product groups have robust estimation results. However, because of the food product group, we apply a (relatively low) 15\%

\footnotetext{
${ }^{9}$ The Hungarian domestic inflation expectations are based on survey data of the European Commission and quantified with the extended Carlson-Parkin method (Gábriel, 2010). The services sector's inflation expectations are based on the ESI indicators published by the European Commission.

${ }^{10}$ The estimation results of the OLS-regression used in the SVAR approach is summarized in Table 6 in the Appendix.
} 
threshold. The reason behind this is, that the price changes of food are more volatile, which brings more uncertainty in the estimation and is reflected in the p-values. Overall, using this $15 \%$ significance level is in line with the SVARestimation literature and is reasonable regarding the volatility of food inflation.

After selecting only the significant explanatory variables we were able to decompose our inflation indicator based on the disaggregated estimation results, which were weighted according to the weights of each main inflation groups. Figure 6 shows the decomposition of the external and domestic inflation drivers in Hungary.

On Figure 6 we can see the average effects of external and internal drivers on the average quarterly change of inflation between 2003-2017. Over the whole sample, the effect of the external drivers is higher than the effect of the internal drivers on inflation. The whole sample can be divided into two subsamples: between 2004 and 2011 the ratio of the effect of both drivers on inflation is nearly equal, but after 2012, the dominance of external drivers is obvious their weight is more than twice as much as the weight of the domestic drivers (Table 1). These results are in line with the results of our PCA estimation and with the literature.

Table 1. Average ratio of the external and internal drivers' effect on inflation (percent)

\begin{tabular}{l|cc} 
& External drivers & Internal drivers \\
\hline $2004-2011$ & 59.3 & 40.7 \\
\hline $2012-2017$ & 72.6 & 27.4 \\
\hline
\end{tabular}

Source: $M N B$

\subsection{Augmenting the traditional Phillips curve specification with measures of global slack}

The Phillips curve is a standard framework for understanding developments in domestic inflation. The traditional Phillips curve focuses on the empirical relationship between domestic slack and inflation. In recent years, the flattening of the Phillips curve can be observed worldwide, suggesting that the influence of domestic slack on price developments has decreased. At the same time, in many countries domestic inflation has become more sensitive to global factors.

Therefore, we examine whether globalization has led to greater sensitivity of domestic inflation to global output gap in Hungary. Based on the existing studies we use an external-factors-augmented Phillips curve approach, which employs measures regarding global slack and global inflation. We therefore study both the domestic and global drivers of the Hungarian inflation, and examine whether and how their relative importance has changed over time. 
Our empirical analysis is based on quarterly data from 2001Q1 to 2017Q2. In contrast with the above applied methods, with the use of the external-factorsaugmented Phillips curve approach we investigated the underlying inflationary processes. Therefore, in the estimation we examined core inflation excluding indirect taxes, as total inflation contains many volatile components. The cyclical position of the domestic economy is measured by the consumption or the output gap in all estimated models. As the latter variable is highly correlated with the foreign output gap used in the equations, their joint use in the same regression is not recommended because of the distorting effect of multicollinearity. A result was provided by a Phillips curve in which both domestic and global factors are represented by variables related to the cyclical position of the economy and which also contains the inflation expectations of the market services sector:

$$
\begin{aligned}
& \pi_{t}^{\text {core }}=\pi_{t}^{\text {target }}+\beta_{1} \pi_{t-1}^{\text {core }}+\beta_{2} \hat{c}_{t-1}+ \\
& +\beta_{3} \hat{y}_{t-2}^{e u}+\beta_{4} e_{t-2}+\beta_{5} \pi_{t}^{e, \text { corp }}+u_{t}
\end{aligned}
$$

where $\pi_{t}^{\text {core }}$ is the annualized quarter-on-quarter change in the core inflation excluding indirect tax effects. Variables $\pi^{\text {target }}, \hat{y}^{e u}$ and $\hat{c}$ are the prevailing inflation target, the output gap of the European Union ${ }^{11}$ and the domestic consumption gap respectively, all expressed in levels. In the equation $e$ indicates the quarterly change in the EUR/HUF nominal exchange rate, $\pi^{e, c o r p}$ indicates the inflation expectations of the market services sector, capturing the forward-looking nature of our Phillips curve specification. ${ }^{12}$

The strengthening role of external factors is confirmed by rolling window estimation of the Phillips curve (Figure 7). The coefficient of the domestic consumption gap is not significant in most of the cases, suggesting that countryspecific effects are losing their importance in core inflation processes. This is in line with the flattening of the Phillips curve estimated using Hungarian data for the period following the crisis. For the whole sample, the coefficient of the EU output gap - capturing global effects - is significantly stronger than the coefficient of the domestic consumption gap, i.e. domestic inflation is more sensitive to global factor. Based on the estimation, if the output gap of the European Union increases by 1 percentage point (p. p), core inflation without tax effects increases by $0.1-$ 0.2 p. p. (Appendix, Table 9). In order to check the robustness of the results, further specifications were estimated, which resulted in similar coefficients concerning the role of external factors (Appendix, Table 10).

\footnotetext{
${ }^{11}$ We use here only the output gap of the EU and do not analyse the effects of the output gap of the Visegrad countries, because approximately $80 \%$ of our foreign trade is with the EU, so the EU output gap is more important than the output gaps of the Visegrad countries.

${ }^{12}$ For summary statistics of the data used for the augmented Phillips curve analysis see Appendix, Table 8.
} 
Figure 7. Rolling window estimation - changes in the coefficients of the domestic consumption gap (left panel) and the EU output gap (right panel) estimated for domestic core inflation
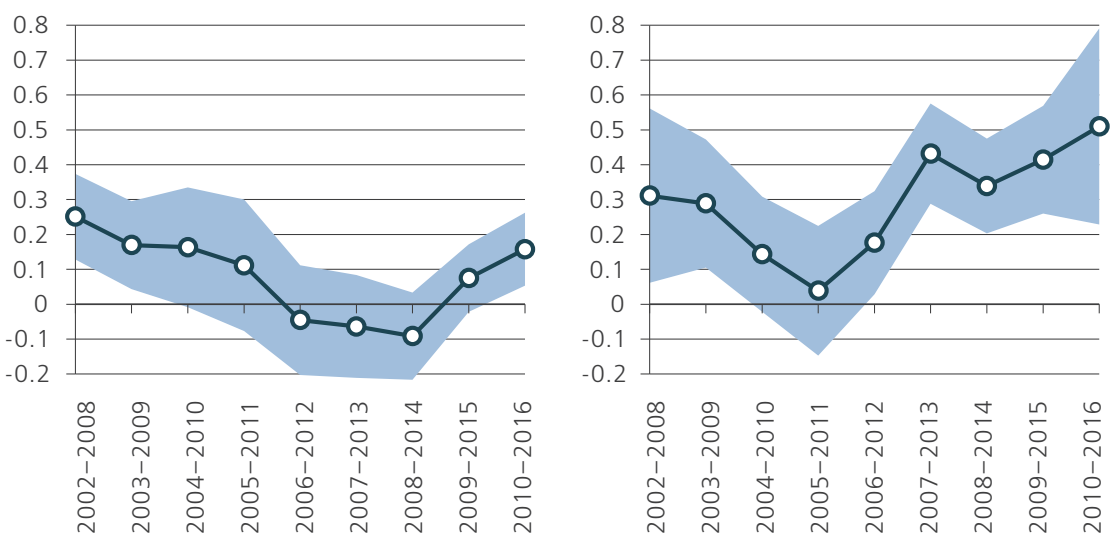

\begin{tabular}{|c|c|c|c|c|c|c|c|c|c|c|c|c|c|c|c|c|c|}
\hline$\infty$ & & 0 & - & $N$ & $m$ & $\checkmark$ & เก & 6 & $\infty$ & の & 0 & - & $\sim$ & $m$ & $\checkmark$ & $\llcorner\cap$ & 6 \\
\hline 잉 & 용 & 5 & 5 & 5 & 5 & 5 & 5 & 5 & 용 & 용 & 5 & 5 & 5 & 5 & 5 & 5 & 5 \\
\hline 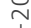 & $\sim$ & $\approx$ & $\sim$ & $\sim$ & $\approx$ & $\sim$ & $\sim$ & $\sim$ & $\sim$ & $\sim$ & $\sim$ & $\sim$ & $\sim$ & $\sim$ & $\sim$ & $\sim$ & $\sim$ \\
\hline$\stackrel{\text { I }}{\sim}$ & 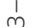 & $\dot{y}^{\prime}$ & ' & l' & $\frac{1}{N}$ & $\begin{array}{l}1 \\
\infty\end{array}$ & '́ & 1 & $\stackrel{\prime}{\sim}$ & I & $\stackrel{1}{+}$ & ' & l & $\frac{1}{1}$ & $\begin{array}{l}1 \\
\infty\end{array}$ & '́ & 1 \\
\hline ᄋ & $\circ$ & ○ & 0 & ○ & ○ & ○ & 8 & 5 & ○ & ○ & ○ & 8 & ○ & 8 & ○ & 8 & 5 \\
\hline & & $\sim$ & $\sim$ & $\sim$ & $\sim$ & $\sim$ & $\sim$ & $\sim$ & $\sim$ & $\sim$ & $\curvearrowright$ & $\sim$ & $\sim$ & $\sim$ & $\sim$ & $\sim$ & $\sim$ \\
\hline
\end{tabular}

Note: The seven-year rolling window regression was estimated on annualised quarterly data. The uncertainty of the estimation indicates one unit of standard deviation.

Source: European Commission, Eurostat, HCSO, MNB

Besides OLS estimations the above specified Phillips curve was also estimated with generalized method of moments (GMM; Hansen, 1982), in order to address the risk of endogeneity of some explanatory variables. ${ }^{13}$ We consider four lags of the domestic consumption gap and the EU output gap, three lags of Hungarian inflation expectations and one lag of the EUR/HUF exchange rate and the core inflation as instruments in the GMM. The lag order is selected based on two information criteria, ${ }^{14}$ allowing for a maximum lag of four quarters. Heteroskedasticity and Autocorrelation Consistent (HAC) estimates were used with a Bartlett kernel and an automatic Newey-West bandwidth selection. The sensitivity of the domestic inflation to global factors is also confirmed by the GMM estimation. The coefficient of the EU output gap is significant and higher than the coefficient of the domestic consumption gap on the whole sample (Appendix, Table 11).

\section{Conclusion}

Inflation rates are declining at global level since 2013. As a result of the rising commodity prices at end-2016 and in early 2017, inflation rates moved away from the close-to-zero levels, but still tended to fall short of central bank targets. Economic performance has varied from region to region after the crisis, which

\footnotetext{
${ }^{13}$ Similar estimations were made by Mikolajun and Lodge (2016) for 19 advanced economies, but they found little support for the existence of direct effects of global economic slack on domestic inflation.

${ }^{14}$ Schwarz's information criterion and the Hannan-Quinn information criterion.
} 
is also corroborated by the significantly different levels of unemployment in the EU. However, despite the different phase of the labour market cycle, no divergence could be detected in inflation dynamics, indeed, inflation rates tended to remain at generally low levels in recent years.

The strengthening correlation between inflation rates may be explained by globalization and - together with that factor - integration into global production processes (the role of global value chains), which may have amplified the impact of international business cycles on inflation. Correlation among the price indices of the EU countries has increased considerably in the past years. In the case of Hungary these are important findings, because the European Union represents the narrower global environment, as approximately $80 \%$ of Hungary's foreign trade is with the EU. Since Hungary became extremely open in the last two decades, we examined the impact of external and domestic drivers of the Hungarian inflation, and we analyzed, how these external factors varied in time and how their effect on the domestic inflation has changed.

On the whole, based on the results of the principal component analysis and the two-step SVAR approach, the role of external factors in domestic inflation developments strengthened in the past period, and after 2012, the changes in inflation in Hungary were mainly influenced by global effects. The strengthening role of the external factors is also confirmed by the changes in the coefficients of the external-factors-augmented Phillips curve estimation. This is in line with the flattening of the Phillips curve estimated using Hungarian data for the period following the crisis. For the whole sample, the coefficient belonging to the output gap of the European Union capturing global effects is significantly stronger than the coefficient of the domestic consumption gap, i.e. domestic inflation is more sensitive to developments in the global factor.

Appendix is available at www.cbr.ru/eng/money-and-finance; dx.doi.org/10.31477/rjmf.201803.49

\section{References}

Auer, R., Levchenko, A. and Sauré, P. (2017). International Inflation Synchronisation Through Global Value Chains. Available at: https://voxeu.org/article/internationalinflation-synchronisation-through-global-value-chains

Bean, C. (2006). Impact of Globalization on Monetary Policy: Commentary. Proceedings of the Economic Policy Symposium, Federal Reserve Bank of Kansas City, pp. 307-316. Available at: https://www.kansascityfed.org/publications/research/escp/symposiums/ escp-2017

Bernanke, B. (2007). Globalization and Monetary Policy. Speech at Fourth Economic Summit, Stanford Institute for Economic Policy Research, Stanford, California. Available at: https://www.federalreserve.gov/newsevents/speech/bernanke20070302a.htm 
Borio, C. (2017). How Much Do We Really Know About Inflation? Speech at the $87^{\text {th }}$ Annual General Meeting, BIS, Basel. Available at: https://www.bis.org/speeches/sp170625a.htm

Borio, C. and Filardo, A. (2007). Globalisation and Inflation: New Cross-Country Evidence on the Global Determinants of Domestic Inflation. BIS Working Papers, N 227.

Borio, C., Auer, R. and Filardo, A. (2017). The Globalization of Inflation: the Growing Importance of Global Value Chains. BIS Working Papers, N 602.

Bulligan, G. and Viviano, E. (2016). Has the Wage Phillips Curve Changed in the Euro Area? Bank of Italy Occasional Paper, N 355.

Calza, A. (2008). Globalization, Domestic Inflation and Global Output Gaps: Evidence from the Euro Area. Federal Reserve Bank of Dallas Working Paper, N 13.

Carney, M. (2015). Inflation in a Globalized World. Proceedings of the Economic Policy Symposium, Federal Reserve Bank of Kansas City, pp. 437-454. Available at: https://www.kansascityfed.org/ /media/files/publicat/ sympos/2015/2015carney.pdf?la=en

Caruana, J. (2012). The Role of Central Banks in Macroeconomic and Financial Stability: the Challenges in an Uncertain and Volatile World. Speech at the CEMLA-SEACEN conference, Punta del Este, Uruguay. Available at: https://www.bis.org/speeches/ sp121116.pdf

Ciccarelli, M. and Mojon, B. (2005). Global Inflation. ECB Working Paper Series, N 537.

Ciccarelli, M. and Mojon, B. (2010). Global Inflation. The Review of Economics and Statistics, 92(3), pp. 524-535.

Draghi, M. (2016). How Central Banks Meet the Challenge of Low Inflation (lecture). Available at: https://www.ecb.europa.eu/press/key/date/2016/html/sp160204.en.html

Dieppe, A., Legrand, R. and van Roye, B. (2016). The BEAR Toolbox. ECB Working Paper Series, N 1934.

ECB Economic Bulletin (2017). Issue 4/2017. Available at: http://www.ecb.europa.eu/pub/ pdf/ecbu/eb201704.en.pdf?48d5da62e60e0368e8f44f3f1639b7e0

Eickmeier, S. and Pijnenburg, K. (2013). The Global Dimension of Inflation - Evidence from Factor-Augmented Phillips Curves. Oxford Bulletin of Economics and Statistics, 75 (1), pp. 103-122.

Fischer, S. (2015). US Inflation Developments. Economic Policy Symposium Proceedings, Federal Reserve Bank of Kansas City, pp. 486-496. Available at: https://www. kansascityfed.org/ /media/files/publicat/sympos/2015/2015fischer.pdf?la=en

Fisher, R. (2006). Coping with Globalization's Impact on Monetary Policy. Speech at the Allied Social Science Association Meetings, Boston.

Gerlach, S., Giovannini, A., Tille C. and Vinals, J. (2009). Are the Golden Years of Central Banking Over? The Crisis and the Challenges. Geneva Reports on the World Economy, 10. Available at: https://cepr.org/sites/default/files/geneva_reports/ GenevaP193.pdf

Guerrieri, L., Gust, C. and López-Salido, J. (2010). International Competition and Inflation: a New Keynesian Perspective. American Economic Journal: Macroeconomics, 2(4), pp. 247-280.

Hałka, A. and Kotłowski, J. (2016). Global or Domestic? Which Shocks Drive Inflation in European Small Open Economies? NBP Working Papers, N 232.

Hansen, L.P. (1982). Large Sample Properties of generalized Method of Moments Estimators. Econometrica, 50(4), pp. 1029-1054. 
Ihrig, J., Kamin, S., Lindner, D. and Marquez, J. (2010). Some Simple Tests of the Globalization and Inflation Hypothesis. International Finance, 13 (3), pp. 343-375.

Jordan, T. (2015). The Impact of International Spillovers on Swiss Inflation and the Exchange Rate. Journal of International Money and Finance, 68 (1), pp. 262-265.

Krusper, B. (2012). The Role of External and Country Specific Factors in Hungarian Inflation Developments. MNB Working Papers, N 5.

Martínez-García, E. and Wynne, M. (2010). The Global Slack Hypothesis. Federal Reserve Bank of Dallas Staff Papers, N 10.

Mikolajun, I. and Lodge, D. (2016). Advanced Economy Inflation: the Role of Global Factors. ECB Working Paper, N 1948.

Milani, F. (2009). Global Slack and Domestic Inflation Rates: A Structural Investigation for G-7 Countries. Federal Reserve Bank of Dallas Working Paper, N 33.

MNB Inflation Report (2017). Available at: https://www.mnb.hu/letoltes/eng-ir-6.pdf

Morimoto, Y., Hirata, W. and Kato, R. (2003). Global Disinflation. Bank of Japan Research Papers, N 13. Available at: https://www.boj.or.jp/en/research/brp/ron_2003/ data/ron0306a.pdf

Mumtaz, H. and Surico, P. (2008). Evolving International Inflation Dynamics: World and Country Specific Factors. Bank of England Working Paper, N 341.

Muto, I. and Shintani, K. (2014). An Empirical Study on the New Keynesian Wage Phillips Curve: Japan and the US. Bank of Japan Working Paper Series, N 14-E-4.

Nickel, C. (2017). The Role of Foreign Slack in Domestic Inflation in the Eurozone. Available at: https://voxeu.org/article/role-foreign-slack-domestic-inflation-eurozone

Poloz, S. (2016). The Paul Storer Memorial Lecture-Cross-Border Trade Integration and Monetary Policy. Bank of Canada Staff Discussion Paper N 20. Available at: https:// www.bis.org/review/r161014d.pdf

Stock, J. H. and Watson, M. W. (2002). Macroeconomic Forecasting Using Diffusion Indexes. Journal of Business \& Economic Statistics, 20 (2), pp. 147-162.

Yellen, J. (2006). Monetary Policy in a Global Environment. Speech at the Euro and the Dollar in a Globalized Economy conference, U.C. Santa Cruz. Available at: https:// www.frbsf.org/our-district/files/060527.pdf 